\title{
White clover soil seed loads: effect on requirements and resultant success of cultivar-change crops
}

\author{
P.T.P. CLIFFORD', I.J. BAIRD', N. GRBAVAC ${ }^{2}$ and G.A. SPARKS \\ ${ }^{1} D S I R$ G rasslands, Private Bag, Christchurch \\ ${ }^{2}$ Seed Testing Station, MAF, P.0. Box 609. Palmerston N orth \\ ${ }^{3} M A F$ Q uality Management, P.0. Box 24, Lincoln
}

\begin{abstract}
A study was done at Canterbury Agriculture and Science Centre, Lincoln, New Zealand, to equate volunteer white clover plant establishment with the decay of the soil seed burden over time. A 5 season break without clover sowings, if coupled with either annual cultivation or herbicide removal of establishing volunteer plants, reduced contamination potential below that desired to meet certification requirements for first-generation seed crops. 'Buried-seed counts' taken after the last deep cultivation for the change crop should be in the $\mathrm{O}-3$ seeds per 50 cores range for breeders' and basic crops and 4-6 per 50 cores for first-generation crops. Sowings to produce breeders' and basic seed must be in $45-\mathrm{cm}$ row spacings to facilitate inter-row herbicide elimination of volunteers. Ministry of Agriculture and Fisheries Seed Testing Station data on 705 potential change crop sites over 5 seasons, indicated that for breeders'-basic and first generation, only $31 \%$ and $50 \%$ of paddocks respectively fell within these ranges, justifying the continued use of this measure as an indicator of potential for success. For the 1989-90 season, $17 \%$ of the 182 first-year autumn-sown cultivar-change certification entries were withdrawn because of poor establishment and/or weed problems, $3 \%$ for wrong sowing methods obviating inspection and $5 \%$ were rejected because of contamination. Currently, the major limitation to growing high yielding white clover change crops, particularly of small-leaved cultivars, is in making seed multipliers aware of available technology.
\end{abstract}

Keywords white clover, contamination, buried seed, volunteer plants, certification

\section{Introduction}

Requirements to ensure that quality standards meet changing commodity and/or market requirements are occasionally imposed in the absence of hard quantitative data. Until such data are obtained, full exploitation of alternative, more efficient production systems available may be limited in the interest of retaining any existing marketplace advantages.

Two of the rules controlling 'cultivar change' in the multiplication of white clover seed (Trifolium repens L.). as imposed by the Seeds Industry Quality Assurance Committee, for both New Zealand-bred and overseas cultivars from the 1985-86 season onwards, fell into this category.

These rules are, firstly, a five-harvest season span without clover sowings and, secondly, annual cultivation to eradicate any volunteer clovers. The mandatory requirements are based on the fact that white clover is 'hard-seeded', i.e., a proportion of seed can remain viable in the soil for many years. When germination does finally occur, contamination of a crop of a different cultivar is possible.

A studymonitoring the fate-of-seed-burdenlosses from soil over time in relation to either annual cultivations or direct-drilling coupled with annual removal of establishing volunteer clovers has now been concluded.

Therefore, as it is 5 years from the inception of rules governing cultivar-change practices, it is pertinent to upgrade knowledge in relation to: 1. information from the buried seed loss study; 2. the validity of using 'buried seed counts' and 3. current success levels within certification.

\section{Research summary}

The site chosen at the Canterbury Agricultural and Science Centre, Lincoln, had had only two successive 'Grasslands Kopu' crops taken for seed over the last 20 years. After the last Kopu harvest (February 1983), the site, containing 4 replicates of 8 randomised subplots each, was direct-drilled with grass. All species were eradicated in late spring of the first season using the non-residual herbicide (glufosinate ammonium $200 \mathrm{~g} / \mathrm{l}$ ai) Buster at $6 \mathrm{I} / \mathrm{ha}$. 
For seasons two to six inclusive (Feb '84-'89), 2 replicates of the old layout were either cultivated to a depth of $100 \mathrm{~mm}$ in early February or sprayed with paraquat (3 1/ha, simulating a direct-drilling alternative). Before the first cultivation, and 13 times over the next 5 seasons, $20 \times 25.4 \mathrm{~mm}$ diameter cores per subplot $\left(100 \mathrm{~m}^{2}\right)$ were taken to a depth of $50 \mathrm{~mm}$ to define both within and seasonal decline patterns. After the initial cultivation only, a SO-100 mm depth sampling was taken to measure seed loss in the nongerminating zone. In late spring of each season, volunteer plants which would flower were counted, then eradicated with Buster herbicide. Apart from the grass in the first season, no sowings were made over the trial duration.

\section{Results}

Before the initial cultivation at the start of the second season (Jan 1984), the seed load in the top $50 \mathrm{~mm}$ of soil was 70,760 and 53,800 seeds $/ \mathrm{m}^{2}$ (425 and 305 $\mathrm{kg} / \mathrm{ha}$ ) respectively for direct-drilled and cultivated options. After the initial cultivation, seed load in the top $50 \mathrm{~mm}$ of soil was reduced to 50,150 and 29,810 seeds $/ \mathrm{m}^{2}, 71 \%$ and $55 \%$ respectively of the intial samplings of the direct-drilling and cultivated practices. Had the initial seed densities of the two options been similar to that of the cultivated treatment, then the advantage to cultivation was the placing of one-sixth, in this instance $50 \mathrm{~kg} / \mathrm{ha}$, of the soil seed-burden from near the surface to down below the germinating (top $50 \mathrm{~mm}$ ) zone.

The fitting of an exponential decay curve to the 13 data sets indicated that the decrease in seed numbers was proportional to the size already attained. The overall rate of soil seed loss for both direct-drilled and cultivated practices was similar, varying only by the amount of seed present at the start of the study (slope $=-0.002925 \pm 0.000226 . \mathrm{DAYS})$. However, variability was greater within the cultivated treatment. This feature was particularly evident in one year where obviously a proportion of the original seed load ploughed down below the germination zone was unintentionally returned to the upper zone. Therefore, where deep ploughing had been practised after the last harvest to remove seed from the germinating zone, all subsequent cultivations, through to and including any cultivar-change crop land preparation, must be at least shallower than the original plough depth if the initial advantage of seed burial is to be retained.

Exponential analysis gave the most satisfactory description of the changes to the soil seed burden over time. This was, for the most part, a function of the changing hard-seed content of the seed burden. By the end of the first season, hard seed content of the soil burden was only 30\%. However, it increased to $96 \%$ by the end of the third season, remaining relatively stable from that point onwards. There were no differences in hard seededness attributable to either time of season or cultural practice. Further, the form of the decay curve would imply that the soil seed burden, had it been measured earlier at postharvest, would have been much higher than the figures given for the end of the first season. Even so, the derived figures still fell within the range recorded by Clifford \& McCartin 1985.

For measurements in the initial season only, plant survival from autumn germinations through to the following spring was similar for both cultural practices $(88 \pm 3.1 \%)$. The fitting of an exponential decay curve to plant survival data also gave a common response for the cultural practice alternatives (slope $=-2.323 \pm 0.222$. SEASONS). Thus, volunteer plant establishment was closely related to germinable seed levels close to the soil surface.

\section{Certification implications}

For ease of interpretation, for a range of harvest losses, soil seed load and associated volunteer plant establishment over time were calculated from the derived regression slopes (Table 1). The numbers in this table for harvest loss and associated soil seed burden over time can be related directly to the opportunity of meeting the lowest certification grade of first generation seed which allows one containment per $10 \mathrm{~m}^{2}$ of crop (MAFQual 1989). Further, due to the common practice response curves, the numbers also relate equally to both annual cultivation and direct-drilling where

Table 1 Seed loss from the soil burden over time and its relationship to established contaminant plants, as calculated from regression slopes, for common cultivation and direct-drilled responses.

\begin{tabular}{|c|c|c|c|c|c|c|c|c|}
\hline \multirow[t]{2}{*}{$\begin{array}{l}\text { Harvest loss } \\
\mathbf{( k g} / \mathrm{ha})\end{array}$} & \multicolumn{6}{|c|}{$\begin{array}{c}\text { Seed numbers and established plant density } / \mathrm{m} \text { ' } \\
\text { seasons }\end{array}$} & \multicolumn{2}{|c|}{6} \\
\hline & Seed & Plants & Seed & Plants & Seed & Plants & Seed & Plants \\
\hline 300 & 50000 & 4890 & 2030 & 47 & 240 & 0.45 & 83 & 0.040 \\
\hline 240 & 40000 & 3920 & 630 & 38 & 190 & 0.36 & 66 & 0.035 \\
\hline 180 & 30000 & 2940 & 220 & 28 & 140 & 0.27 & 50 & 0.027 \\
\hline 120 & 20000 & 1960 & 815 & 19 & 96 & 0.18 & 33 & 0.018 \\
\hline 60 & 10000 & 980 & 410 & 9 & $* 48$ & 0.09 & 17 & 0.009 \\
\hline 6 & 1000 & 98 & 41 & 0.9 & 5 & 0.009 & 2 & 0.0009 \\
\hline
\end{tabular}

*Densities meet first generation certification standard of one offtype or less per $10 \mathbf{~ m}^{2}$. 
associated with annual herbicide removal of volunteer clover plants prior to flowering.

Only for the abnormally low potential harvest losses of $60 \mathrm{~kg} / \mathrm{ha}$ or less was this minimum standard for certification achieved within 5 seasons. For the sixth season, however, all harvest loss situations (6-300 kg/ha) met minimum certification requirements. Overall, time between crops of one cultivar and that of another, per se, rather than the amount of seed lost at the last harvest, was the prime factor in meeting certification standards. Thus, there seems to be no scope for reducing the time interval below the current mandatory 5-year period. The 3 -year-only requirement of OECD regulations is totally unacceptable (Anon. 1985).

Offsetting the maintenance of the current timespan limitation, this study has indicated that direct-drilling of alternative species is a viable option, provided that volunteer plants are removed annually with herbicide before flowering. In line with this finding, the associated regulation was amended for autumn 1990 sowings (MAFQual 1990).

For both breeders' and basic seed change crops, sowing in $45-\mathrm{cm}$ row spacings (to facilitate inter-row removal of volunteers where necessary) would also seem to be a mandatory requirement. At present, the greatest limitation to ease of growing consistently high-yielding change crops is the lack of adequate technology to eliminate volunteer plants at the minimum specified row spacing of $30 \mathrm{~cm}$.

\section{Buried seed counts}

For an allocation of seed of a change cultivar, most seed merchants now require a buried seed count fo the paddock as evidence of potential to meet certification standards. Suggested standards for, a 50-core sample per site, to be taken after any final deep working for seed bed preparation, have been assessed for breeders' seed as 0-3 seeds per 50 cores $\left(0-120\right.$ seeds $\left./ \mathrm{m}^{*}\right)$ and for basic seed as 4-6 seeds per 50 cores $\left(160-240\right.$ seeds $\left./ \mathrm{m}^{2}\right)$ (Anon. 1987). From the data presented in Table 1, which indicated an upper limit for first generation certified seed of 5 seeds per 50 cores without a roguing requirement, the present range from 0-6 seeds per $\mathbf{5 0}$ cores appears adequate. Sowings to produce basic seed, however, would be better sited in paddocks in the $0-3$ seeds per 50 core range.

\section{Current certification experience}

Information on buried seed counts for 705 intended cultivar-change sites over 5 seasons from the MAF Seed Testing Station files are presented in Table 2. Only $31 \%$ fell within the breeders'-basic requirements of 0-3 seeds per 50 cores and $50 \%$ for first generation certification standards of 4-6 seeds per 50 cores. These means do not take into account either the obvious variations among seasons, or the extremes of up to 125 seeds per 50 cores encountered on more than one occasion. Therefore, the minimal cost of a buried seed determination is more than justified in relation to a major revenue loss where a crop fails to meet certification standards.

For the 1989-90 season, cultivar-change crops accounted for $20 \%$ of all white clover entries. Of these 255 entries, 69 were second harvest crops, with only one re-entry rejected at field inspection owing to contamination (Table 3): overall, $17 \%$ of the autumn-sown change crops entered were withdrawn; the reason stated was poor establishment, e.g., weed problems and frost-lift. The small-leaved cultivars, 'Grassland Tahora' and Ab S184, predominated in this category (respectively $48 \%$ and $40 \%$ of these cultivar crops sown). For these cultivars, however, yields of $800 \mathrm{~kg} / \mathrm{ha}$ have been gained using existing technology (J.D. Duncan, Challenge Seeds Ltd. pers. comm.). This feature highlights the need for other programmes similar to the Emerging Technologies between DSIR Grasslands and Challenge Seeds Ltd, whereby-growers' crops-are-individually -monitored by experts to upgrade grower awareness of all aspects of multiplication requirements.

Six crops had to be withdrawn for not meeting 'specified' sowing requirements for crop inspection. The methods not allowed included drilled at $15 \mathrm{~cm}$ centres, diagonals drilled, and cross-drilled. Of those remaining, only 9 crops $(5 \%)$ were rejected for contamination.

Table 2 Buried seed count ranges for the number of paddocks submitted in each year.

\begin{tabular}{|c|c|c|c|c|c|}
\hline \multirow[b]{2}{*}{ Year } & \multicolumn{4}{|c|}{ Seed numbers per 50 cores } & \multirow{2}{*}{$\begin{array}{c}\text { Total } \\
\text { Paddocks }\end{array}$} \\
\hline & $0-3$ & $4-6$ & $7-9$ & $<10$ & \\
\hline 1986 & $53(34)^{*}$ & $28(18)$ & $20(13)$ & $54(35)$ & 155 \\
\hline 1987 & $64(32)$ & 37 (19) & $22(11)$ & $75(38)$ & 198 \\
\hline 1988 & $53(25)$ & 47 (22) & $15(7)$ & 97 (46) & 212 \\
\hline 1989 & $33(34)$ & 17 (17) & 18 (19) & $29(30)$ & 97 \\
\hline 1990 & $15(35)$ & $4(9)$ & $7(16)$ & $17(40)$ & 43 \\
\hline Mean $(\%)$ & 31 & 19 & 12 & 38 & \multirow{2}{*}{705} \\
\hline Range $(\%)$ & $25-35$ & $9-22$ & $7-19$ & $30-46$ & \\
\hline
\end{tabular}

)$^{*}=\%$ of paddocks in each category per annum. 
Table 3 Fate of white clover cultivar-change entries for certification in the 1989-90 season.

\begin{tabular}{|c|c|c|c|c|c|}
\hline \multirow[b]{2}{*}{ Cultivar } & \multirow[b]{2}{*}{ No. of entries } & \multicolumn{2}{|c|}{ Withdrawal } & \multirow{2}{*}{$\begin{array}{l}\text { No. rejected } \\
\text { owing to } \\
\text { contamination }\end{array}$} & \multirow{2}{*}{$\begin{array}{l}\text { Withdrawal- } \\
\text { rejection } \\
(\%)\end{array}$} \\
\hline & & $\begin{array}{l}\text { Wrong sowing } \\
\text { technique }\end{array}$ & $\begin{array}{c}\text { Poor } \\
\text { establishment }\end{array}$ & & \\
\hline $\begin{array}{l}\text { Koou }{ }^{1} \\
\text { Pitau } \\
\text { Tahora }^{1,2}\end{array}$ & $\begin{array}{l}13 \\
57 \\
23\end{array}$ & $\begin{array}{l}0 \\
0 \\
0\end{array}$ & $\begin{array}{l}3 \\
1 \\
6\end{array}$ & $\begin{array}{l}0 \\
0 \\
5\end{array}$ & $\begin{array}{r}23 \\
2 \\
48\end{array}$ \\
\hline $\mathrm{Ab} \mathrm{S184^{2 }}$ & 10 & 0 & 4 & 0 & 40 \\
\hline Alban & 8 & 0 & 0 & 0 & 0 \\
\hline Alice & 14 & 0 & 2 & 0 & 14 \\
\hline Aran & 38 & 0 & 6 & 0 & 16 \\
\hline Donna & 15 & 0 & 1 & 0 & 7 \\
\hline Gwenda & 3 & 0 & 1 & 0 & 33 \\
\hline Karina & 3 & 0 & 0 & 0 & 0 \\
\hline Lirepa & 9 & 0 & 3 & 0 & 33 \\
\hline Menna & 20 & 0 & 1 & 3 & 20 \\
\hline Olwen & 20 & 4 & 2 & 2 & 40 \\
\hline Ramona & 1 & 0 & 0 & 0 & 0 \\
\hline Si wan & 8 & 2 & 0 & 0 & 25 \\
\hline Sonja & 11 & 0 & 1 & 0 & 9 \\
\hline Susi & 2 & 0 & 0 & 0 & 0 \\
\hline Totals & 255 & 6 & 31 & 10 & \\
\hline
\end{tabular}

${ }^{1}$ Grasslands cultivars (NZ) ${ }^{2}$ small-leaved cultivars

\section{Conclusions}

1. To minimise the soil seed burden in the germinating zone, deep ploughing of last seed harvest seed losses and then annual shallow cultivations or direct-drilling plus herbicide removal of volunteers over 5 years should be practised.

2. Buried seed counts done immediately before the white clover change and after any deep soil workings are more than justifiable, but only as an indicator of the likely degree of success.

3. For at least breeders' and basic seed crops, paddocks in the O-3 seeds per 50 core range should be selected and with ALL change crops drilled at $45-\mathrm{cm}$ row spacings to allow inter-row herbicide treatment.

\section{ACKNOWLEDGEMENTS}

The analysts, MAF Seed Testing Station, Palmerston North; Certification collators, MAF Quality Management, Christchurch; Ms E. Stevenson, DSIR, Applied Maths, for statistical analyses of research study data.

\section{REFERENCES}

Anon. 1985. OECD Scheme for the varietal certification of herbage and oil seed moving in international trade. Appendix II - Minimum requirements for the production of basic and certified seed under the OECD Herbage and Oil seed scheme (Decision of 9 Oct 1973 and amendments to 1985).

Anon. 1987. Analytical Services. pp. 8-16, In Annual Report 1986, Official Seed Testing Station, Ministry of Agriculture and Fisheries, Palmerston North, New Zealand.

Clifford, P.T.P.; McCartin, S.J.M. 1985. Effects of preharvest treatment and mower and header types on seed loss and hard seed content at mowing, recovery and separation when harvesting a white clover seed crop. NZ journal of experimental agriculture 13: 307-3 16.

MAFQual, 1989. Seed Certification 1989-90. MAFQual Christchurch, $71 \mathrm{pp}$.

MAFQual, 1990. Seed Certification and Seed Testing Circular Number 281. $1 \mathrm{p}$. 